\title{
Some Molecular and Clinical Aspects of Genetic Predisposition to Malignant Melanoma and Tumours of Various Site of Origin
}

\author{
Tadeusz Dębniak \\ International Hereditary Cancer Centre, Department of Genetics and Pathology, Szczecin, Poland
}

Key words: $C D K N 2 A, A R F, X P D, M C 1 R$, melanoma, breast cancer, family history, age at diagnosis, cancer risk, mutation analysis, Poland

Corresponding author: Tadeusz Dębniak, International Hereditary Cancer Centre, Department of Genetics and Pathology, Szczecin, Poland, e-mail: debniak@wp.pl

Submitted: 7 May 2007

Accepted: 16 May 2007

\begin{abstract}
Based on epidemiological data we can assume that at least some malignant melanoma (MM) and breast cancer cases can be caused by the same genetic factors. CDKN2A, which encodes the p16 protein, a cyclin-dependent kinase inhibitor suppressing cell proliferation, is regarded as a major melanoma susceptibility gene and the literature has also implicated this gene in predisposition to breast cancer. Genes also known to predispose to $M M$ include XPD and MC1R. We studied CDKN2A/ARF, XPD and MCIR for their associations with melanoma and breast cancer risk in Polish patients and controls. We found that CDKN2A and ARF do not contribute significantly to either familial melanoma or malignant melanoma within the context of a cancer familial aggregation of disease with breast cancer. However, the common variant of the CDKN2A gene A148T, previously regarded as non-pathogenic, may predispose to malignant melanoma, early-onset breast cancer and lung cancer. Compound carriers of common XPD variants may be at slightly increased risk of breast cancer or late-onset malignant melanoma. Common recurrent variants of the MC1R gene (V60L, R151C, R163Q and R160W) may predispose to malignant melanoma. In general, the establishment of surveillance protocols proposed as an option for carriers of common alterations in CDKN2A, XPD or MC1R variants requires additional studies. It is possible that missense variants of genes for which truncating mutations are clearly pathogenic may also be deleterious, but with reduced penetrance. This may be overlooked unless large numbers of patients and controls are studied. A registry that includes 2000 consecutive breast cancer cases, 3500 early onset breast cancer patients, 500 unselected malignant melanoma and over 700 colorectal cancer patients has been established in the International Hereditary Cancer Centre and can contribute to these types of large association studies.
\end{abstract}

\section{Introduction}

Based on epidemiological data we can assume that at least some malignant melanoma (MM) and breast cancer cases can be caused by the same genetic factors. CDKN2A, which encodes the p16 protein, a cyclin-dependent kinase inhibitor suppressing cell proliferation, is regarded as a major melanoma susceptibility gene and the literature has also implicated this gene in predisposition to breast cancer. Genes also known to predispose to MM include XPD and MCIR. This paper reviews a range of studies which have been performed in Polish populations with the following objectives: 
1. Assessment of the risk of malignancies of various sites of origin in relatives of malignant melanoma patients from families with strong familial cancer aggregation.

2. Assessment of germline mutation and large deletion analysis of the CDKN2A/ARF genes in families with multiple melanomas and in families with an aggregation of malignant melanoma and breast cancer.

3. Determination of the association of CDKN2A common variants with melanoma risk.

4. Assessment of breast cancer risk among carriers of the common CDKN2A variants.

5. Assessment of clinical characteristics of CDKN2A-positive breast cancers in young women.

6. Assessment of CDKN2A common variants and multi-organ cancer risk.

7. Assessment of XPD common variants and their association with melanoma and breast cancer risk.

8. Assessment of MC1R common variants, CDKN2A and their association with melanoma and breast cancer risk.

\section{Risk of malignancies of various site of origin in relatives of malignant melanoma patients from families with strong cancer familial aggregation}

(based on Debniak T, Gorski B, Cybulski C, Jakubowska A, Kurzawski G, Kladny J, Zaluga E, Fiedorowicz J, Debniak B, Lubinski J. Increased risk of breast cancer in relatives of malignant melanoma patients from families with strong cancer familial aggregation. Eur J Cancer Prev 2003; 12: 241 -245)

Population screening for familial aggregation of malignancies performed recently by our centre for the West Pomeranian region of Poland (population $1.5 \mathrm{~m}$ ) has shown that among families with strong aggregation of tumours the most frequently diagnosed situation is the occurrence of cancer familiar aggregations with unknown pathogenetic background (CFA). CFA do not match pedigree/clinical criteria of any known cancer family syndromes and they are characterized by occurrence of malignancies of various sites of origin among at least three first-degree relatives. It is important to perform analyses to clarify the background of the CFA in order to predict their clinical behaviour, and eventually discern how to defeat them.

One of the tumours that can occur in families with CFA is malignant melanoma (MM). It has been shown that constitutional BRCA1 mutations lead to familial cancer aggregations of not only breast/ovarian cancers but also MM [1]. In addition, it has been suggested that in some families $M M$ can be caused by a predisposition to tumours of various sites [2-4].

The aim of this study was to evaluate the risk of occurrence of malignancies of various sites in patients with $M M$ and their first-degree relatives from families with CFA.

\section{Materials and methods}

The pedigree and clinical data of a series of 175 consecutive patients with MM who underwent surgery at the Regional Oncology Hospital in Szczecin in the period from 1997 to 2001 were reviewed in order to select cases with histologically confirmed MM of the skin and family history of at least two more first-degree relatives affected by malignancies of various site of origin (MM/CFA). Families with two or more MM cases among first-degree relatives were considered as familial melanomas and excluded from this study.

We identified 51 families with MM/CFA and analyzed the tumour spectrum and age at diagnosis of malignancies in these families, and compared it to the general Polish population.

The study was approved by the ethics board of the Pomeranian Medical University in Szczecin.

\section{Results}

Analysis of distribution of age at diagnosis of $M M$ from MM/CFA families revealed two peaks of occurrence of melanoma cases at the ages 45-50 and 65-70 years. Thus, we identified a subgroup of 22 MM/CFA families with MM diagnosed before 55 years with a total number of 75 malignancies among relatives of patients with $M M$; and a subgroup of 29 MM/CFA families with MM diagnosed after 55 and with a total number of 78 malignancies among relatives of patients with $M M$.

Evaluation of the tumour spectrum in these families revealed an increased proportion of breast cancers: $17.52 \%$ in the subgroup of $\leq 55 \mathrm{MM} / \mathrm{CFA}$ families, $12.15 \%$ in the subgroup of $>55$ MM/CFA families.

We also observed an increased proportion of liver cancer, CSU (cancer site unknown) and leukaemia.

Evaluation of the mean age at diagnosis revealed that breast cancers appear at a younger age in comparison with the general population; mean age of diagnosis in $\leq 55$ MM/CFA families was 48.47 years (Table 1).

Statistical analyses revealed a higher than expected observed frequency of occurrence of breast cancers 
Table 1. Proportion and age at diagnosis of malignancies of various site of origin in relatives of MM patients from MM/CFA families

\begin{tabular}{|c|c|c|c|c|c|c|c|c|}
\hline \multirow[t]{2}{*}{ Tumour site } & \multicolumn{3}{|c|}{$\leq 55 \mathrm{MM} / \mathrm{CFA}$ families } & \multicolumn{3}{|c|}{$>55 \mathrm{MM} / \mathrm{CFA}$ families } & \multicolumn{2}{|c|}{ General population' } \\
\hline & $\begin{array}{l}\text { frequency } \\
(\%)\end{array}$ & $\begin{array}{l}\text { odds } \\
\text { ratio }\end{array}$ & $\begin{array}{l}\text { mean age } \\
\text { at diagnosis }\end{array}$ & $\begin{array}{l}\text { frequency } \\
(\%)\end{array}$ & $\begin{array}{l}\text { odds } \\
\text { ratio }\end{array}$ & $\begin{array}{l}\text { mean age } \\
\text { at diagnosis }\end{array}$ & $\begin{array}{c}\text { frequency } \\
(\%)\end{array}$ & $\begin{array}{l}\text { mean age } \\
\text { at diagnosis }\end{array}$ \\
\hline breast & $17(17.52)^{3}$ & 2.14 & $48.47^{3}$ & $13(12.15)$ & - & 50.85 & 8.96 & 58.5 \\
\hline$\leq 50$ years & $10(10.3)^{3}$ & 3.71 & - & $8(7.5)^{3}$ & 2.61 & - & 2.77 & - \\
\hline$>50$ years & $7(7.2)$ & - & - & $5(4.7)$ & - & - & 6.19 & - \\
\hline lungs & $11(11.34)$ & - & 61.13 & $10(9.34)^{3}$ & - & 62.23 & 19.15 & 64 \\
\hline colon & $6(6.19)$ & - & 65.4 & $9(8.41)$ & - & 67.3 & 9.68 & 62 \\
\hline stomach & $3(3.09)$ & - & 61.9 & $6(5.60)$ & - & 61.4 & 5.95 & 67 \\
\hline liver & $4(4.12)$ & - & 66.9 & $6(6.54)^{3}$ & - & 67.7 & 1.77 & 67 \\
\hline skin $^{4}$ & $3(3.09)$ & - & 61.8 & $5(4.67)$ & - & 62.1 & 4.47 & 67.6 \\
\hline leukaemia & $3(4.12)$ & \multicolumn{2}{|c|}{ not done } & 0 & \multicolumn{2}{|c|}{ not done } & 1.95 & not done \\
\hline $\mathrm{CSU}^{2}$ & $12(12.38)^{3}$ & \multicolumn{2}{|c|}{ not done } & $8(7.47)^{3}$ & \multicolumn{2}{|c|}{ not done } & 0.42 & not done \\
\hline
\end{tabular}

'general Polish population (Zatoński W, Tyczyński J. Nowotwory w Polsce w 1999. Krajowy rejestr nowotworów, Warszawa 2001)

211 cases of ovarian, uterine or cervical cancer $6.1 \%$, site of origin not confirmed

${ }^{3} p<0.05$, statistically significant

${ }^{4}$ skin cancers

(OF $10.48 \%$ versus EF $4.54 \%$ ) in MM/CFA families $\leq 55 \mathrm{MM} / \mathrm{CFA}$. Related risk of occurrence of breast cancers was especially increased in $\leq 55 \mathrm{MM} / \mathrm{CFA}$ families - 3.256 (Table 2).

\section{Summary of the results}

We analysed tumour spectrum and age at diagnosis of malignancies in 51 families with MM/CFA. Families of patients with $M M$ diagnosed $<56$ years of age showed an increased proportion of breast cancer (OF $10.6 \%, E F=4.3 \%$, mean age of diagnosis 48.5 years) and a higher proportion of diagnosis of breast cancer in younger age $(<50$ years of age, $O R=3.7 ; R R=3.3)$.

\section{Germline mutation and large deletion analysis of the CDKN2A/ARF genes in families with multiple melanomas and in families with an aggregation of malignant melanoma and breast cancer}

(based on Debniak T, Gorski B, Scott RJ, Cybulski C, Medrek K, Zowocka E, Kurzawski G, Debniak B, Kadny J, Bielecka-Grzela S, Maleszka R, Lubinski J. Germline mutation and large deletion analysis of the CDKN2A and ARF genes in families with multiple melanoma or an aggregation of malignant melanoma and breast cancer. Int J Cancer 2004; 1 10: 558-562)

The results of previous studies show increased risk of malignant melanoma (MM) in families with multiple members affected by disease and in families characterized by the constellation of breast cancer and MM. The reason for that may be shared molecular base of breast cancer and $M M$, like for example injury of the CDKN2A gene. In the literature, there are some differences concerning the frequency of constitutional mutations of the CDKN2A gene in carriers with familiar aggregation of $M M$ in different populations [5-8]. In Polish familial MM (FMM), no CDKN2A mutations have been detected to date [9].

CDKN2A shares exons 2 and 3 with another gene, $A R F$, which has also been implicated in the pathogenesis of MM [10]. Hewitt et al. described a germline mutation of ARF in patients affected with melanoma or breast cancer from a family with multiple melanomas and breast cancers [11]. No studies examining $A R F$ in families with aggregations of $M M$ and breast cancer have been reported.

Methods used to screen for mutations in CDKN2A/ARF are usually PCR-based and focus on the detection of small sequence alterations, such as point mutations, small deletions and insertions. Only a few authors have searched for large CDKN2A/ARF deletions or rearrangements $[6,12]$. A novel method to analyze 
Table 2. Results of statistical analyses (expected and observed frequency, related risk of occurrence of malignancies of various site of origin) in MM/CFA families

\begin{tabular}{|c|c|c|c|}
\hline Tumour site' & Observed frequency (OF \%) & Expected frequency (EF \%) & Relative risk (RR, $\mathrm{Cl} 95 \%$ ) \\
\hline \multicolumn{4}{|l|}{ breast $^{2}$} \\
\hline$\leq 55 \mathrm{MM} / \mathrm{CFA}$ & $14^{2}(10.6)$ & $5.68(4.3)$ & $3.256(\mathrm{Cl} 95 \% 0.95-6.8)^{4}$ \\
\hline$>55 \mathrm{MM} / \mathrm{CFA}$ & $13^{2}(9.8)$ & $11.35(8.6)$ & 1.145 (Cl 95\% 0.54-2.45) \\
\hline \multicolumn{4}{|l|}{ lungs } \\
\hline males & $17(5.6)$ & $12.57(4.1)$ & $1.352(\mathrm{Cl} 95 \% 0.63-2.934)$ \\
\hline females & $4(1.3)$ & $2.95(0.9)$ & 1.358 (Cl 95\% 0.258-7.678) \\
\hline \multicolumn{4}{|l|}{ colon } \\
\hline males & $8(2.6)$ & $5.17(1.7)$ & 1.547 (Cl 95\% 0.47-5.306) \\
\hline females & $7(2.2)$ & $4.59(1.5)$ & 1.526 (Cl 95\% 0.427-5.723) \\
\hline \multicolumn{4}{|l|}{ stomach } \\
\hline males & $5(1.6)$ & $3.11(1.0)$ & 1.609 (Cl 95\% 0.344-8.232) \\
\hline females & $4(1.3)$ & $2.59(0.8)$ & $1.543(\mathrm{Cl} 95 \% 0.278-9.577)$ \\
\hline \multicolumn{4}{|l|}{ liver } \\
\hline males & $4(1.3)$ & $2.24(0.7)$ & 1.786 (Cl95\% 0.301-12.53) \\
\hline females & $6(1.9)$ & $2.50(0.8)$ & 2.396 (Cl 95\% 0.497-13.83) \\
\hline \multicolumn{4}{|l|}{$\operatorname{skin}^{3}$} \\
\hline males & $5(1.6)$ & $3.41(1.1)$ & 1.465 (Cl 95\% 0.326-7.06) \\
\hline females & $3(1.0)$ & $3.88(1.2)$ & $0.773(\mathrm{Cl} 95 \% 0.137-4.107)$ \\
\hline
\end{tabular}

1 breast cancer was studied in two separate groups, the remaining tumours in one group (51 families with MM/CFA)

2 women only, 3 cases of bilateral or metachronic breast cancer and 1 case of breast cancer in a man were excluded from further study

${ }^{3}$ skin cancer (basocellular or spinocellular)

${ }^{4} \mathrm{p}<0.05$

large genomic alterations, multiplex ligation-dependent probe amplification (MLPA), has been described, enabling rapid and sensitive screening for the identification of genomic rearrangements $[13,14]$.

To determine whether the CDKN2A and ARF genes are involved in Polish FMM and aggregations of breast cancer and $M M$, we applied genomic sequencing and MLPA analysis to the molecular characterization of these genes in DNA samples obtained from FMM patients and from CFA families with MM and breast cancer.

\section{Materials and methods}

\section{Patients}

We examined 3 groups of families: group 1 (FMM cases), MM probands from 16 families with at least 2 first-degree relatives affected with MM registered at the Hereditary Cancer Centre in Szczecin; group 2 (44 cases), probands diagnosed with $\mathrm{MM}$ and having at least 2 first-degree relatives, one affected with breast cancer and the other diagnosed with either breast cancer or a malignancy at a different site; group 3 (22 cases), family defined by the index patient being diagnosed with breast cancer, a first-degree relative with melanoma and a family history of at least one more first-degree relative affected by any malignancy.

For restriction fragment length polymorphism (RFLP) analysis, DNA samples from 200 healthy individuals selected at random by family doctors from the city of Szczecin (controls) were used.

\section{Methods}

Genomic DNA was prepared from peripheral blood leukocytes [15]. Purified PCR products were sequenced 
directly using the Big-Dye Terminator, version 3.0 (Perkin-Elmer, Foster City, CA), sequencing reaction with the same forward primers used previously for exonic amplification of the CDKN2A and ARF genes. Sequencing reaction products were separated and analyzed on an ABI 377 DNA Sequencer (Perkin-Elmer).

For the analysis of large deletions and insertions, the SALSA P024 CDKN2A/2B (9p21) was used. After PCR amplification of exon 2 of CDKN2A, products were digested with restriction enzymes BseLI and CFR42I (both from MBI Fermentas, Vilnius, Lithuania).

The study was approved by the ethics board of the Pomeranian Medical University in Szczecin.

\section{Results}

In group 1, there were 16 probands screened for mutations in the CDKN2A/ARF genes. From this set of families, there were 2 cases identified, one of which harboured a common polymorphism (A148T) and the other a previously unidentified missense change (R99G).

In group 2, of 44 probands, 3 patients (6.8\%) were identified who harboured the same common polymorphism as defined above. Only one case in group 3 harboured the A1 48T change. In the control group, there were 7 cases of 200 probands (3.5\%).

There were no changes in exon 1 of the ARF gene from any of the probands of the 3 groups. However, the R99G change identified in CDKN2A translates to a P144R change in the ARF expressed sequence, both of which may result in a functional change in activity. The rare variant identified in the FMM proband was further analyzed in 200 individuals who had not been reported to be affected by any malignancy. The results revealed an absence of the R99G change in the control population, suggesting that it is associated with disease risk.

The presence of large deletions or insertions was evaluated using the MLPA assay, and in none of the 3 groups were gross rearrangements of the CDKN2A/ARF genes observed.

\section{Summary of the results}

From 16 families with strong aggregations of MM and from 66 families with breast cancer and the other diagnosed with either breast cancer or with strong aggregations of malignancy at a different site, only 6 families with CDKN2A constitutional mutations were diagnosed. Two different changes in the CDKN2A gene were detected $-\mathrm{A} 148 \mathrm{~T}$ variant was found in 5 families, and R99G was found in one family.

\section{CDKN2A common variants and their association with melanoma risk}

(based on Debniak T, Scott RJ, Huzarski T, Byrski T, Rozmiarek A, Debniak B, Zaluga E, Maleszka R, Kladny J, Gorski B, Cybulski C, Gronwald J, Kurzawski G, Lubinski J. CDKN2A common variants and their association with melanoma risk: a population-based study. Cancer Res 2005; 65: 835-839)

There have been 77 causative CDKN2A variants listed in the international melanoma mutation database, eMelanoBase. CDKN2A (OMIM 60160) was the first to be associated with MM risk and is regarded as the major MM susceptibility gene. The frequency of these CDKN2A variants in the reported populations remains undetermined; however, because they result in an altered protein product they are considered to account for rare familial forms of the disease. Two common polymorphisms in the $3^{\prime}$ untranslated region of CDKN2A have also been described as being associated with a modulation of risk or disease progression. However, one study indicates that there is no overrepresentation of the $\mathrm{N}+500 \mathrm{c}>\mathrm{g}$ and the N+540c>t variants in the melanoma population [16-18]. Based on the results of the previous paper, it was shown that in Poland, apart from the two polymorphisms in the $3^{\prime}$ untranslated region, there is one more common variant of CDKN2A - an alanine to threonine substitution at codon 148 (A148T) - which has been estimated to be present in approximately $3.5 \%$ of the population. Functional studies suggest this variant is a polymorphism, which seems to have no major affect on pl 6 function $[19,20]$. Previous studies have shown that the A148T polymorphism is in linkage disequilibrium with the promoter polymorphism P-493, which has been shown to affect gene expression $[21,22]$. Nevertheless, the A148T change has been found to be overrepresented in melanoma kindreds (3\%) in comparison to the general population (1.8\%) [18].

To establish whether the A148T, N+500c $>g$, and the $\mathrm{N}+540 \mathrm{c}>t$ variants are associated with increased melanoma risk we carried out an association study based on genotyping 471 patients with $M M$ and 1,210 random control subjects from the same Polish population.

\section{Materials and methods}

\section{Patients}

The unselected case group consisted of 471 patients with MM, comprising: a) 301 unselected patients with MM diagnosed in northwestern Poland (Szczecin, 
Gorzów Wlkp, Zielona Góra); b) 80 unselected consecutive MM cases diagnosed in northeastern Poland (Białystok); c) 90 unselected consecutive MM cases diagnosed in southwest Poland (Opole).

The control population consisted of 500 consecutive newborns from the clinical hospitals of Szczecin and 710 controls selected at random from the computerized patient lists of five family practices in Szczecin, Białystok and Opole.

\section{Methods}

The A148T variant was analyzed by RFLP PCR; PCR products were digested with the Sacll enzyme. The $\mathrm{N}+500 \mathrm{c}>\mathrm{g}$ and the $\mathrm{N}+540 \mathrm{c}>t$ variants were analyzed by RFLP PCR; PCR products were digested with the Aval and Haelll enzymes.

In cases positive in RFLP PCR, DNA samples were sequenced to confirm the presence of the mutation.

The study was approved by the ethics board of the Pomeranian Medical University in Szczecin.

\section{Results}

The frequency of the A $148 \mathrm{~T}$ change was assessed in the two control populations (newborns versus adults) and the frequencies were $2.8 \%$ and $2.95 \%$. There were no large differences in the frequencies of the $\mathrm{N}+500 \mathrm{c}>\mathrm{g}$ alleles and in the frequencies of the $\mathrm{N}+540 \mathrm{c}>t$ alleles in the two control populations (Table 3). Because these were not statistically significant (data not shown), combined control population frequencies were used for statistical analyses of both of these CDKN2A changes.

There was no evidence that the genotype frequencies of the three CDKN2A variants deviated from those expected under Hardy-Weinberg for the control group or any of the melanoma groups.

In the melanoma population under study the frequency of the A148T variant was significantly greater than that observed in the control population. There were no large differences in the frequencies of the $\mathrm{N}+500 \mathrm{c}>\mathrm{g}$ alleles or in the frequencies of the $\mathrm{N} 540 \mathrm{c}>$ t alleles (Table 3).

To further determine the importance of the A148T change, its frequency was assessed in patients who were $<50$ years of age and compared with those $>50$ years. The results reveal that the frequency is greater in the $<50$-year-old group compared with the $>50$ -year-old group. The OR was consequently greater in the younger age group $(O R=3.5 ; P=0.0007)$ compared with the older group $(\mathrm{OR}=2.1 ; \mathrm{P}=0.0351)$. The mean age of $\mathrm{A} 148 \mathrm{~T}$ carriers was 53 years and the mean age of non-carriers was 55 years; this was not statistically significant $(P=0.632)$.
To further define the association of the A148T change and its link to malignancy we examined the occurrence of cancer of any type in first-degree relatives of carriers compared with non-carriers. Familial melanoma cases were excluded from this evaluation. This analysis revealed that the carrier population was more likely to have a relative with malignancy compared with the non-carrier population (57\% versus $36 \%$, respectively; $P=0.03)$.

Because there is doubt about the functional consequence of the A $148 \mathrm{~T}$ change, but it is in linkage disequilibrium with a promoter polymorphism that affects gene expression levels, 20 A148T heterozygous carriers and $20 \mathrm{~A} 148 \mathrm{~T}$ non-carriers were studied to determine the proportion of samples that were linked. The results revealed that all $\mathrm{A} 148 \mathrm{~T}$ heterozygous carriers were heterozygous $\mathrm{A} / \mathrm{T}$ carriers at position $\mathrm{P}-493$ and all $\mathrm{A} 148 \mathrm{~T}$ non-carriers were $\mathrm{A} / \mathrm{A}$ homozygous carriers at position P-493.

\section{Summary of the results}

From 471 unselected patients with $M M$, the A148T change was found in $7 \%$ of patients, and the $\mathrm{N}+500 \mathrm{c}>\mathrm{g}$ and $\mathrm{N}+540 \mathrm{c}>+$ variants were found in $23.6 \%$ and in $20 \%$ of patients, respectively. All estimate changes were significantly greater in the case group than those observed in the control population. Statistically significant data show that the A148T $(O R=2.5)$ variant seems to be associated with an increased risk of developing MM, insignificantly higher in cases diagnosed $<50$ years of age $(O R=3.4)$. There were no substantial differences in MM diagnosed in middle age, among carriers and non-carriers of A148T change.

\section{Breast cancer risk among carriers of the common CDKN2A variant}

(based on Debniak T, Gorski B, Huzarski T, Byrski T, Cybulski C, Mackiewicz A, Gozdecka-Grodecka S, Gronwald J, Kowalska E, Haus O, Grzybowska E, Stawicka M, Swiec M, Urbanski K, Niepsui S, Wasko B, Gozdz S, Wandzel P, Szczylik C, Surdyka D, Rozmiarek A, Zambrano O, Posmyk M, Narod SA, Lubinski J. A common variant of CDKN2A (p 16 ) predisposes to breast cancer. J Med Genet 2005; 42: 763-765)

Candidate genes for cancers of a particular site may be selected because they are known to predispose to malignancies of other organs, or because they are mutated somatically in the cells from the cancer of interest. It is possible that missense variants of genes for 
Table 3. Frequencies of CDKN2A variant alleles in cases and controls

\begin{tabular}{|c|c|c|c|c|c|c|}
\hline Groups & $\mathrm{A} 148 \mathrm{~T}$ & OR 95\% Cl & $\mathrm{N}+500 \mathrm{c}>\mathrm{g}$ & OR $95 \% \mathrm{Cl}$ & $N+540 c>t$ & OR $95 \% \mathrm{Cl}$ \\
\hline newborns & $0(0 \%) \mathrm{A} / \mathrm{A}$ & - & $6(1.2 \%) \mathrm{G} / \mathrm{G}$ & - & $4(0.8 \%) \mathrm{T} / \mathrm{T}$ & - \\
\hline \multirow[t]{2}{*}{$(n=500)$} & 14 (2.8\%) G/A & - & $88(17.6 \%) \mathrm{G} / \mathrm{C}$ & - & $62(12.4 \%) \mathrm{C} / \mathrm{T}$ & - \\
\hline & 486 (97.2\%) G/G & - & $406(81.2 \%) \mathrm{C} / \mathrm{C}$ & - & 434 (86.8\%) C/C & - \\
\hline adults & $0(0 \%) \mathrm{A} / \mathrm{A}$ & - & 9 (1.3\%) G/G & - & $3(0.4 \%) \mathrm{T} / \mathrm{T}$ & - \\
\hline \multirow[t]{2}{*}{$(n=710)$} & 21 (2.95\%) G/A & - & 143 (20.1\%) G/C & - & $83(11.7 \%) \mathrm{C} / \mathrm{T}$ & - \\
\hline & $689(97.05 \%) \mathrm{G} / \mathrm{G}$ & - & $558(78.6 \%) \mathrm{C} / \mathrm{C}$ & - & 625 (88\%) C/C & - \\
\hline total & $0(0 \%) \mathrm{A} / \mathrm{A}$ & - & $15(1.2 \%) \mathrm{G} / \mathrm{G}$ & - & $7(0.6 \%) \mathrm{T} / \mathrm{T}$ & - \\
\hline controls & 35 (2.89\%) G/A & - & 229 (18.9\%) G/C & - & 145 (12\%) C/T & - \\
\hline \multirow[t]{2}{*}{$(n=1210)$} & $1175(97.1 \%) G G$ & - & $966(79.8 \%) \mathrm{C} / \mathrm{C}$ & - & $1058(87.4 \%) C / C$ & - \\
\hline & Allel A 1.5\% & - & Allel G 10.7\% & - & Allel T $6.6 \%$ & - \\
\hline $\mathrm{MM}^{*}$ & $0(0 \%) \mathrm{A} / \mathrm{A}$ & - & $8(1.7 \%) \mathrm{G} / \mathrm{G}$ & $1.4^{4} 0.6-3.3$ & $3(0.6 \%) \mathrm{T} / \mathrm{T}$ & $1.1^{4} 0.3-4.3$ \\
\hline \multirow[t]{3}{*}{$(n=471)$} & 33 (7\%) G/A & $2.5^{1} 1.5-4.1$ & $103(21.9 \%) \mathrm{G} / \mathrm{C}$ & $1.2^{4} 0.9-1.6$ & $64(13.5 \%) \mathrm{C} / \mathrm{T}$ & $1.2^{4} 0.8-1.6$ \\
\hline & 438 (93\%) G/G & $0.4^{1} 0.2-0.6$ & $360(76.4 \%) C / C$ & $0.8^{4} 0.6-1.1$ & 404 (85.7\%) C/C & $0.9^{4} 0.6-1.2$ \\
\hline & Allel A 3.5\% & $2.5^{1} 1.5-4.0$ & Allel G 12.6\% & $1.2^{4} 0.9-1.5$ & Allel T 7.4\% & $1.1^{4} 0.9-1.5$ \\
\hline melanoma & $0(0 \%) \mathrm{A} / \mathrm{A}$ & - & $1(0.6 \%) \mathrm{G} / \mathrm{G}$ & $0.5^{4} 0.1-3.6$ & $2(1.2 \%) \mathrm{T} / \mathrm{T}$ & $2.0^{4} 0.4-9.8$ \\
\hline & $16(9.3 \%) \mathrm{G} / \mathrm{A}$ & $3.4^{2} 1.9-6.4$ & 32 (18.6\%) G/C & $1.0^{4} 0.6-1.5$ & $21(12.2 \%) \mathrm{C} / \mathrm{T}$ & $1.0^{4} 0.6-1.7$ \\
\hline \multirow{2}{*}{$(n=172)$} & $156(90.7 \%) \mathrm{G} / \mathrm{G}$ & $0.3^{2} 0.2-0.5$ & $139(80.8 \%) \mathrm{C} / \mathrm{C}$ & $1.1^{4} 0.7-1.6$ & 149 (86.6\%) C/C & $0.9^{4} 0.6-1.5$ \\
\hline & Allel A $4.7 \%$ & $3.3^{2} 1.8-6.1$ & Allel G 9.9\% & $0.9^{4} 0.6-1.3$ & Allel T 7.3\% & $1.1^{4} 0.7-1.7$ \\
\hline melanoma & $0(0 \%) \mathrm{A} / \mathrm{A}$ & - & $7(2.3 \%) \mathrm{G} / \mathrm{G}$ & $1.9^{4} 0.8-4.7$ & $1(0.3 \%) \mathrm{T} / \mathrm{T}$ & $0.6^{4} 0.1-4.7$ \\
\hline$>50$ & 17 (5.7\%) G/A & $2.0^{3} 1.1-3.7$ & $71(23.7 \%) \mathrm{G} / \mathrm{C}$ & $1.3^{4} 1.0-1.8$ & $43(14.4 \%) \mathrm{C} / \mathrm{T}$ & $1.2^{4} 0.9-1.8$ \\
\hline \multirow[t]{2}{*}{$(n=299)$} & 282 (94.3\%) G/G & $0.5^{3} 0.3-0.9$ & 221 (73.9\%) C/C & $0.7^{4} 0.5-0.9$ & 255 (85.3\%) C/C & $0.8^{4} 0.6-1.2$ \\
\hline & Allel A 2.8\% & $2.0^{3} 1.1-3.6$ & Allel G 14.2\% & $1.4^{4} 1.0-1.8$ & Allel T 7.5\% & $1.2^{4} 0.8-1.6$ \\
\hline
\end{tabular}

*unselected malignant melanomas;

${ }^{1} p=0.0003,{ }^{2} p=0.0002,{ }^{3} p=0.0315,{ }^{4} p \geq 0.05$ - not statistically significant

which truncating mutations are clearly pathogenic may also be deleterious, but with reduced penetrance. In this situation the association may be overlooked unless large numbers of cancers are studied. The CDKN2A (OMIM 600160) gene is a tumour suppressor gene that is involved in susceptibility to malignant melanoma and has also been implicated in familial pancreatic cancer [23]. The pl6 protein is a cyclin-dependent kinase inhibitor that suppresses cell proliferation and is expressed in a wide range of tissues, including the breast, and in breast cancers [24]. In a previous study [reference], it was shown that patients with the A148T variant have higher predisposition to $M M$ (an alanine to threonine substitution at codon 148) $(O R=2.5$; $p=0.0003)$. It has been suggested by Borg and colleagues that protein truncating CDKN2A mutations predispose women to breast cancer in the context of a syndrome of melanoma, pancreatic cancer and breast cancer [22]. They observed eight cases of breast cancer in Swedish families, compared with the 2.1 expected $(p=0.002)$. There are few other data on this topic. Ghiorzo et al. observed a non-significant excess of breast cancers in seven melanoma families with CDKN2A mutations $(O R=1.9 ; 95 \%$ confidence interval $(C l)$, 0.4 to 5.6) [25]. Somatic CDKN2A mutations have not been well studied in breast cancers, but silencing of CDKN2A through methylation appears to be a relatively common way of inactivating this tumour suppressor gene in the breast [26]. Furthermore, deletion or loss of heterozygosity at the CDKN2A locus (9p21) is relatively common in breast cancers [27].

To establish whether this common missense variant of CDKN2A predisposes to breast cancer we undertook an association study on 4209 cases of breast cancer and 3000 ethnically matched controls from Poland.

\section{Materials and methods}

During 1997-2003 in 18 treatment centres throughout Poland family history and DNA samples were obtained from 3318 patients with breast cancer diagnosed before the age of 51 . In a companion study, seven of these centres also provided data on unselected breast cancer in 891 cases diagnosed above the age of 50 between 2000 and 2002.

The control group comprised 2000 newborn and 1000 adults from the region of Szczecin unselected for cancer family history.

The study was approved by the ethics board of the Pomeranian Medical University in Szczecin. 


\section{Laboratory methods}

The A148T variant was analyzed by PCR-RFLP. PCR products were digested with the Sacll enzyme. The presence of the A148T change was confirmed by direct DNA sequencing.

\section{Results}

The A148T variant was detected in 105 from 3000 cases from the control group (3.5\%), 5.1\% of breast cancer patients diagnosed at age 50 or below and in $4.5 \%$ of cases diagnosed at age 51 and above (Table $4)$. For women diagnosed below age 51 the odds ratio was $1.5(p=0.002)$. For women diagnosed over age 50 the odds ratio was modest and non-significant $(O R=1.3 ; p=0.2)$. In the small group of patients diagnosed with breast cancer at age 30 and under, the prevalence of the CDKN2A variant was $12.1 \%$ and the association was much stronger $(O R=3.8 ; p=0.0002)$.

Among the 3318 women diagnosed with breast cancer under age 50, 692 had a family history of a firstor second-degree relative with breast cancer. For the familial and non-familial cases there were no differences observed in frequencies of the A148T variant.

However, the frequency of the A $148 \mathrm{~T}$ alleles was similar in the newborn population (3.5\%) and the adult population (3.6\%). The allele was equally frequent among males (3.5\%) and females (3.6\%) and among controls recruited from Szczecin (3.5\%) and from elsewhere in Poland (3.6\%).

\section{Summary of the results}

We have shown that the A148T allele of the CDKN2A gene is overrepresented in a population of 3318 unselected patients with breast cancer under age 50 , and also in 891 unselected patients with breast cancer at age 50 and above. The statistical significant differences concern risk of breast cancer obtained only in the group of patients with cancer diagnosed in young age $(<51$ years of age, $O R=1.5)$.

\section{Clinical characteristics of CDKN2A- -positive breast cancers in young women from Poland}

(based on Debniak T, Cybulski C, Gorski B, Huzarski T, Byrski T, Gronwald J, Jakubowska A, Kowalska E, Oszurek O, Narod SA, Lubinski J. CDKN2A-positive breast cancers in young women from Poland. Breast Cancer Res Treat 2006)

The results of previous papers suggest that the frequent $\mathrm{A} 148 \mathrm{~T}$ change in the CDKN2A gene is associated with higher frequency not only of $M M$ but also of breast cancer in young age ( $\leq 50$ years of age).

To investigate the contribution of the A148T variant to early-onset breast cancer, and to establish the characteristic features of these cancers, we studied 3069 early-onset breast cancer cases and 3439 population controls.

\section{Materials and methods}

The case group consisted of 3267 cases with breast cancer diagnosed under 51 years of age, unselected in relation to family history. Among these, 198 women carried one of the three Polish founder BRCA1 mutations (4153delA, 5328insC, C61G) and were excluded from the present study. Information was recorded on age at diagnosis, stage, grade and lymph-node status, oestrogen-receptor status, multicentricity and bilaterality. The medical record and pathology report were reviewed locally by the physician associated with the study.

Table 4. Frequencies of CDKN2A variant alleles in breast cancer patients

\begin{tabular}{lccccc}
\hline Age & Number tested & Mutation positive & Prevalence [\%] & Odds ratio & $p$ \\
\hline $\mathbf{5 0}$ years & & & & & \\
\hline $20-30$ & 66 & 8 & 12.10 & 3.8 & 0.0002 \\
\hline $31-40$ & 582 & 24 & 4.10 & 1.2 & 0.46 \\
\hline $41-50$ & 2670 & 136 & 5.10 & 1.5 & 0.003 \\
\hline total & 3318 & 168 & 5.10 & & 0.002 \\
\hline$>50$ years & & & & 1.3 & 0.17 \\
\hline $51+$ & 891 & 40 & 4.50 & & \\
\hline
\end{tabular}


The control group consisted of 2051 newborn children from hospitals throughout Poland, and 1442 healthy adults unselected for cancer family history.

The study was approved by the ethics board of the Pomeranian Medical University in Szczecin.

\section{Results}

An A148T variant was identified in 157 of 3069 women with breast cancer in young age $15.1 \%$; $\mathrm{OR}=1.4 ; 95 \% \mathrm{Cl} 1.075-1.725 ; \mathrm{P}=0.012)$.

The characteristics of breast cancer cases in the 157 women with CDKN2A variant were compared with non-carriers (Table 5). The mean age of diagnosis in women with an A148T variant was similar to that in the non-carriers cases. The distribution of histological types was similar in cases and controls. However, carriers of A 148T variant were more likely to be diagnosed with intraductal cancers (DCIS) with micro-invasion than were non-carriers (14.8\% vs. 8.5\%; $\mathrm{P}=0.035)$. Lobular cancers were less frequent among carriers when compared to non-carriers (16.6\% vs. $1.3 \%$ ), although this difference was not significant $(P=0.58)$.

Carriers and non-carriers were similar with respect to tumour size; there were no significant differences between the groups (Table 5). Carriers and non-carriers were similar with respect to oestrogen-receptor status (67\% vs. $64 \% ; P=0.6)$. Bilateral tumours were equally common in both subgroups (3.6\% vs. $3.4 \%$; $P=0.9$ ), multicentric cancers were also not over-represented in any of the groups $(20 \%$ vs. $18 \% ; P=0.6)$.

There was no difference in cancer family history between carriers and non-carriers of the A148T variant $-7.5 \%$ of the carriers were from a family with two or more first-degree relatives with breast cancer versus $9 \%$ of the non-carriers $(P=0.64)$.

\section{Summary of the results}

The study of 3069 cases with breast cancers certifies that carriers of the A $148 \mathrm{~T}$ variant were slightly more likely to develop intraductal cancers (DCIS) with micro-invasion than non-carriers (14.8\% vs. $8.5 \%$; $\mathrm{P}=0.035)$. There was no difference between carriers and non-carriers with respect to tumour size, laterality, multicentricity, nodal status, family history or oestrogen receptor status.

\section{CDKN2A common variant and multi-organ cancer risk}

(based on Debniak T, Scott RJ, Huzarski T, Byrski T, Rozmiarek A, Debniak B, Gorski B, Cybulski C,
Medrek K, Mierzejewski M, Masojc B, Matyjasik J, Zlowocka E, Teodorczyk U, Lener M, Klujszo-Grabowska E, Nej-Wolosiak K, Jaworowska E, Oszutowska D, Szymanska A, Szymanska J, Castaneda J, van de Wetering T, Suchy J, Kurzawski G, Oszurek O, Narod S, Lubinski J. CDKN2A common variant and multi-organ cancer risk - a population-based study. Int J Cancer 2006; 118: $3180-3182$ )

The CDKN2A variant can be found in tumours of many organs, among others head and neck cancer, respiratory malignancies and laryngeal cancer [28-30]. The p 16 protein is expressed in a wide range of tissues, and the full range of cancers associated with CDKN2A mutations has yet to be determined.

Data from the literature indicate a possible association between CDKN2A, A148T and common $M M$. There is also some evidence to indicate that this variant is associated with breast cancer at younger age. We had also observed that the A 148T heterozygous carrier population was more likely to have a first-degree relative with cancer of any type compared to the MM carrier population $(p=0.03)$.

To determine whether this A148T change may be associated with an increased risk of malignancies at various sites of origin, we genotyped a series of 3,583 unselected cancer cases and compared the frequency of the change observed in this population to 3,000 controls.

\section{Materials and methods}

Cases were enrolled in the study from hospitals in Szczecin and surrounding counties. Study subjects were unselected for age, sex or family history. In general, more than $75 \%$ of patients agreed to take part in the studies. Two control groups were combined. The first group consisted of 2,000 newborn children from ten hospitals throughout Poland. The second control group consisted of 1,000 unselected adults from the region of Szczecin.

The method of examining and verifying the A $148 \mathrm{~T}$ variant was shown previously.

The study was approved by the ethics board of the Pomeranian Medical University in Szczecin.

\section{Results}

The A 1 48T variant was detected in 3.5\% of Polish controls. The frequency of the alleles was similar in the newborn population (3.4\%) compared to the adult population $(P=0.83)$. There was no statistical difference 
Table 5. Comparison of CDKN2A-positive and CDKN2A-negative breast cancer cases

\begin{tabular}{|c|c|c|c|c|}
\hline Parameters & & $\begin{array}{c}\text { p16-positive } \\
\text { n=157 }\end{array}$ & $\begin{array}{c}\text { pl6-negative } \\
n=2912\end{array}$ & $\mathrm{p}$ \\
\hline age (mean) & & 44.35 & 44.34 & 0.9 \\
\hline \multirow[t]{3}{*}{ age group } & $20-30$ & 6/157 (3.82\%) & $51 / 2912(1.75 \%)$ & 0.11 \\
\hline & $31-40$ & $21 / 157$ (13.38\%) & $501 / 2912(17.2 \%)$ & 0.25 \\
\hline & $41-50$ & 130/157 (82.80\%) & $2360 / 2912(81.04 \%)$ & 0.66 \\
\hline \multirow[t]{8}{*}{ histology } & "low grade" & $32 / 108(29.63 \%)$ & $637 / 2012(31.66 \%)$ & 0.74 \\
\hline & "high grade" & 15/108 (13.88\%) & $303 / 2012$ (15.06\%) & 0.85 \\
\hline & medullary & 6/108 (5.55\%) & $112 / 2012(5.57 \%)$ & 0.99 \\
\hline & lobular & 18/108 (16.66\%) & $388 / 2012(19.28)$ & 0.58 \\
\hline & tubulo-lobular & 6/108 (5.55\%) & $89 / 2012$ (4.42\%) & 0.75 \\
\hline & DCIS & 16/108 (14.81\%) & $170 / 2012(8.45 \%)$ & 0.04 \\
\hline & other & 15/108 (13.88\%) & $313 / 2012(15.56 \%)$ & 0.74 \\
\hline & no data or unknown & 12/108 (1 1.11\%) & 225/2012 (1 1.18\%) & 0.89 \\
\hline $\begin{array}{l}\text { pre-operative } \\
\text { chemotherapy }\end{array}$ & positive & $37 / 151$ (24.5\%) & $675 / 2012(24.5 \%)$ & 0.99 \\
\hline ER & positive & $61 / 91$ (67.03\%) & $1085 / 1698$ (63.9\%) & 0.58 \\
\hline \multirow[t]{4}{*}{ tumour size } & $<1 \mathrm{~cm}$ & $9 / 99$ (9.09\%) & 185/1767 (10.47\%) & 0.87 \\
\hline & $1-1.9 \mathrm{~cm}$ & $43 / 99(43.43 \%)$ & 798/1767 (45.16\%) & 0.76 \\
\hline & $2-4.9 \mathrm{~cm}$ & $46 / 99(46.46 \%)$ & $742 / 1767$ (42\%) & 0.72 \\
\hline & $>5 \mathrm{~cm}$ & $1 / 99$ (1.01\%) & $42 / 1767(2.38 \%)$ & 0.73 \\
\hline nodal status & positive & $37 / 100(37 \%)$ & 752/1801 (41.75\%) & 0.4 \\
\hline multi-centricity & present & 18/90 (20\%) & $340 / 1898$ (17.91\%) & 0.58 \\
\hline laterality & present & $5 / 138(3.62 \%)$ & $88 / 2573(3.42 \%)$ & 0.96 \\
\hline family history & positive $(+)$ & $11 / 146(7.5 \%)$ & $240 / 2658$ (9\%) & 0.64 \\
\hline
\end{tabular}

For all comparisons, except age, bilaterality and family history, cases with pre-operative chemotherapy were excluded. Family history refers to a first-degree relative affected with breast cancer

in the CDKN2A allele frequencies in the newborns recruited from the Szczecin metropolitan region compared to other Polish cities. There was no evidence that the genotype frequencies of the A148T variant deviated from those expected under Hardy-Weinberg (HWE) for the control groups ( $p>0.4$ ).

The prevalence of the A148T variant was higher in cancer cases than in controls for three of the eleven sites studied (Table 6). The highest odds ratios were observed among lung cancer $(\mathrm{OR}=2.0$ ) and colon cancer $(O R=1.5)$ cases. For lung the excess was statistically significant (adjusted $p$ value after Bonferroni correction 0.0052), and was non-significant for colorectal cancer (unadjusted $p$ value 0.0423 , adjusted $p$-value 0.5499 ) (Table 6).

Odds ratios were further analyzed by taking into account the age of disease onset $(\leq 50,>50)$. There were no significant differences between early-onset lung cancers $(5 / 70 ; 7.1 \%)$ and late-onset cancers (29/427; 6.8\%). The A148T prevalence was slightly higher in late-onset colorectal cancers (5.1\%) than in early-onset cases (4.9\%) (the number of patients with colon cancer diagnosed under age 50 was less (n 5 122), thereby reducing the power of this result). 
Table 6. Association between A148T variants and selected types of cancer

\begin{tabular}{|c|c|c|c|c|}
\hline Cases & $\mathrm{A} 148 \mathrm{~T}$ & OR & $95 \%$ confidence interval & $\mathrm{p}$ (adjusted) \\
\hline controls & $0(0 \%) \mathrm{A} / \mathrm{A}$ & - & - & - \\
\hline \multirow[t]{3}{*}{$(n=3000)$} & 105 (3.5\%) G/A & - & - & - \\
\hline & 2895 (96.5\%) G/G & - & - & - \\
\hline & Allele A frequency $1.75 \%$ & - & - & - \\
\hline bladder & $0(0 \%) \mathrm{A} / \mathrm{A}$ & - & - & - \\
\hline \multirow[t]{3}{*}{$(n=223)$} & $7(3.1 \%) \mathrm{G} / \mathrm{A}$ & 0.9 & $0.4105-1.945$ & 0.7764 (n.s.) \\
\hline & $216(96.9 \%) \mathrm{G} / \mathrm{G}$ & 1.1 & $0.5142-2.436$ & 0.7764 (n.s.) \\
\hline & Allele A frequency $1.6 \%$ & 0.9 & $0.4012-1.876$ & 0.7177 (n.s.) \\
\hline colon & $0(0 \%) \mathrm{A} / \mathrm{A}$ & - & - & - \\
\hline \multirow[t]{3}{*}{$(n=724)$} & 37 (5.1\%) G/A & 1.5 & $1.012-2.180$ & $0.0423(0.5499)$ \\
\hline & $687(94.9 \%) \mathrm{G} / \mathrm{G}$ & 0.7 & $0.459-0.989$ & $0.0423(0.5499)$ \\
\hline & Allele A frequency $2.6 \%$ & 1.5 & $1.008-2.151$ & $0.0443(0.5759)$ \\
\hline stomach & $0(0 \%) \mathrm{A} / \mathrm{A}$ & - & - & - \\
\hline \multirow[t]{3}{*}{$(n=246)$} & $8(3.3 \%) \mathrm{G} / \mathrm{A}$ & 0.9 & $0.4461-1.925$ & 0.8384 (n.s.) \\
\hline & $238(96.7 \%) \mathrm{G} / \mathrm{G}$ & 1.1 & $0.5194-2.241$ & 0.8384 (n.s.) \\
\hline & Allele $\mathrm{A}$ frequency $1.6 \%$ & 0.9 & $0.4494-1.916$ & 0.8398 (n.s.) \\
\hline larynx & $0(0 \%) \mathrm{A} / \mathrm{A}$ & - & - & - \\
\hline \multirow[t]{3}{*}{$(n=396)$} & 17 (4.3\%) G/A & 1.2 & $0.7326-2.088$ & 0.4255 (n.s.) \\
\hline & $379(95.7 \%) \mathrm{G} / \mathrm{G}$ & 0.8 & $0.4790-1.365$ & 0.4255 (n.s.) \\
\hline & Allele A frequency $2.1 \%$ & 1.2 & $0.7337-2.067$ & 0.4298 (n.s.) \\
\hline ovary & $0(0 \%) \mathrm{A} / \mathrm{A}$ & - & - & - \\
\hline \multirow[t]{3}{*}{$(n=340)$} & $12(3.5 \%) \mathrm{G} / \mathrm{A}$ & 1.0 & $0.5491-1.853$ & 0.9777 (n.s.) \\
\hline & $328(96.5 \%) \mathrm{G} / \mathrm{G}$ & 1.0 & $0.5396-1.821$ & 0.9777 (n.s.) \\
\hline & Allele A frequency $1.8 \%$ & 1.0 & $0.5520-1.843$ & 0.9779 (n.s.) \\
\hline lung & $0(0 \%) \mathrm{A} / \mathrm{A}$ & - & - & - \\
\hline \multirow[t]{3}{*}{$(n=497)$} & $34(6.8 \%) \mathrm{G} / \mathrm{A}$ & 2.0 & $1.358-3.018$ & $0.0004(0.0052)$ \\
\hline & $463(93.2 \%) \mathrm{G} / \mathrm{G}$ & 0.5 & $0.331-0.736$ & $0.0004(0.0052)$ \\
\hline & Allele A frequency $3.4 \%$ & 2.0 & $1.342-2.945$ & $0.0005(0.0065)$ \\
\hline prostate & $0(0 \%) \mathrm{A} / \mathrm{A}$ & - & - & - \\
\hline \multirow[t]{3}{*}{$(n=348)$} & $13(3.7 \%) \mathrm{G} / \mathrm{A}$ & 1.1 & $0.5946-1.925$ & 0.8215 (n.s.) \\
\hline & $335(96.3 \%) \mathrm{G} / \mathrm{G}$ & 0.9 & $0.5194-1.682$ & 0.8215 (n.s.) \\
\hline & Allele A frequency $1.9 \%$ & 1.1 & $0.5972-1.912$ & 0.8231 (n.s.) \\
\hline kidney & $0(0 \%) \mathrm{A} / \mathrm{A}$ & - & - & - \\
\hline \multirow[t]{3}{*}{$(n=264)$} & $6(2.3 \%) \mathrm{G} / \mathrm{A}$ & 0.6 & $0.2788-1.474$ & 0.2915 (n.s.) \\
\hline & $258(97.7 \%) \mathrm{G} / \mathrm{G}$ & 1.6 & $0.6782-3.586$ & 0.2915 (n.s.) \\
\hline & Allele A frequency $1.1 \%$ & 0.6 & $0.2820-1.477$ & 0.2957 (n.s.) \\
\hline thyroid & $0(0 \%) \mathrm{A} / \mathrm{A}$ & - & - & - \\
\hline \multirow[t]{3}{*}{$(n=173)$} & $3(1.7 \%) \mathrm{G} / \mathrm{A}$ & 0.5 & $0.1528-1.549$ & 0.2129 (n.s.) \\
\hline & 170 (98.3\%) G/G & 2.1 & $0.6454-6.545$ & 0.2129 (n.s.) \\
\hline & Allele A frequency $0.9 \%$ & 0.5 & $0.1550-1.556$ & 0.2169 (n.s.) \\
\hline nonHodgkin & $0(0 \%) \mathrm{A} / \mathrm{A}$ & - & - & - \\
\hline lymphoma & $6(3.7 \%) \mathrm{G} / \mathrm{A}$ & 1.1 & $0.4585-2.453$ & 0.8909 (n.s.) \\
\hline \multirow[t]{2}{*}{$(n=162)$} & 156 (96.3\%) G/G & 0.9 & $0.4077-2.181$ & 0.8909 (n.s.) \\
\hline & Allele A frequency $1.9 \%$ & 1.0 & $0.4616-2.431$ & 0.8918 (n.s.) \\
\hline pancreas & $0(0 \%) \mathrm{A} / \mathrm{A}$ & - & - & - \\
\hline \multirow[t]{3}{*}{$(n=210)$} & $8(3.8 \%) \mathrm{G} / \mathrm{A}$ & 1.1 & $0.5246-2.273$ & 0.8140 (n.s.) \\
\hline & $202(96.2 \%) \mathrm{G} / \mathrm{G}$ & 0.9 & $0.4400-1.906$ & 0.8140 (n.s.) \\
\hline & Allele A frequency $1.9 \%$ & 1.1 & $0.5275-2.253$ & 0.8156 (n.s.) \\
\hline
\end{tabular}




\section{Summary of the results}

In the study of 3583 unselected patients with tumours of many organs (other than MM and breast cancer) the A 1 48T variant was detected more often than among patients with lung cancer $(6.8 \% ; O R=2.0 ; P=0.0004$ adjusted $p$ value after Bonferroni correction $P=0.0052$ ) or colon cancer $(5.1 \% ; \mathrm{OR}=1.5, \mathrm{P}=0.0423$; adjusted $\mathrm{p}$ value after Bonferroni correction $\mathrm{P}=0.5499)$.

\section{XPD common variants and their association with melanoma and breast cancer risk}

(based on Debniak T, Scott RJ, Huzarski T, Byrski T, Masoic B, van de Wetering T, Serrano-Fernandez P, Gorski B, Cybulski C, Gronwald J, Debniak B, Maleszka R, Kladny J, Bieniek A, Nagay L, Haus O, Grzybowska E, Wandzel P, Niepsuj S, Narod SA, Lubinski J. XPD common variants and their association with melanoma and breast cancer risk. Breast Cancer Res Treat 2006; 98: 209-215)

There is continuing interest in identifying low-penetrance genes, which are associated with increased susceptibility to common types of cancer. The genetic basis of $M M$ is complex and appears to involve multiple genes. Individuals with the rare inherited syndrome xeroderma pigmentosum (XP) have an approximate 1000-fold increased incidence of skin malignancies, including melanoma [31]. There are several genes associated with XP and these include ERCC2, ERCC3, XP-G and XP-F [31, 32]. The XPD (ERCC2) gene product has a dual function in basal transcription and in nucleotide excision repair $[33,34]$. In the literature there are four reports evaluating XPD gene polymorphisms and melanoma risk. Two of them were performed on a very small number of cases [35, 36], whereas the other two suggested a modest positive association of two single nucleotide polymorphisms in exons 10 (Asp312Asn) and 23 (Lys751 Gln) with either melanoma or a subset of older onset cases of melanoma based on 219 and 176 melanoma cases, respectively [37, 38]. Recently the two XPD variants (Asp312Asn and Lys751 Gln) have also been linked with the occurrence of breast cancer [39, 40]. Interestingly, the positive findings for Asp312Asn in the 223 Finnish unselected breast cancer patients were not repeated in 172 Polish familial cases [41].

To establish whether the XPD common variants Asp312Asn and Lys751Gln are associated with increased melanoma or breast cancer risk we performed an association study based on genotyping 426 unselected patients with MM and 1830 consecutive breast cancer cases compared to 1262 geographically matched newborns and 1553 healthy adults.

Additionally we examined the prevalence of Gly156Gly, Leu485Pro and Arg 1 12His variants in XPD among 421 unselected melanoma patients as it is unknown whether these SNPs are associated with disease risk.

\section{Materials and methods}

The first case group of 471 unselected patients with MM consisted of: a) 301 unselected patients with MM diagnosed in northwestern Poland (Szczecin, Gorzów Wlkp, Zielona Góra); b) 80 unselected consecutive MM cases diagnosed in northeastern Poland (Białystok); c) 90 unselected consecutive MM cases diagnosed in southwest Poland (Opole).

The second case group consisted of cases of consecutive invasive breast cancer diagnosed at 7 treatment centres throughout Poland, unselected for age and family history (including 511 cases in the vicinity of Szczecin). A detailed family history of cancer was ascertained. A total of 2500 incident cases of invasive breast cancer were identified at the 7 different centres during the study period. Of these, 1900 women accepted the invitation to participate in this genetic study (76\%). From the total of 1900 enrollees 70 patients could not be genotyped because of poor quality DNA. This brought the total number of breast cancer cases studied to 1830 .

The first control group consisted of 1262 geographically matched newborn male and female children collected in the same hospitals from where the melanoma and breast cancer cases were collected.

The second control group consisted of 621 adults from the region of Szczecin unselected for cancer family history.

The third control group consisted of 421 healthy adults matched for sex and age with the melanoma cases and 511 healthy adults from the region of Szczecin matched for sex and age with the breast cancer cases collected from the city of Szczecin.

The XPD changes were analyzed by PCR-RFLP, using the enzymes: Psp 14061 for Asp312Asn; Pstl for Lys $751 \mathrm{Gln}$; Tfil for Gly $156 \mathrm{Gly}$; Hpall for Leu485Pro; Faul for Arg $112 \mathrm{His}$. DNA sequencing was undertaken on random samples to ensure that all PCR products represented the respective XPD alleles.

The study was approved by the ethics board of the Pomeranian Medical University in Szczecin.

\section{Results}

There were no significant differences in the allele frequencies of the XPD variants in all three control 
populations; also among newborns recruited from treatment centres throughout Poland and among males and females there were no significant differences. Since only the newborn group consisted of cases geographically matching the melanoma and breast cancer patients, and as it was larger than the adult control population, further statistical calculations were performed only on this control group.

The expected allelotype distributions for all polymorphisms were in Hardy-Weinberg equilibrium.

We were unable to evaluate an association between melanoma and Arg 112His and Leu485Pro since neither of these polymorphisms were represented among the control and subject populations used in this study, suggesting that both changes are very rare in the Polish population.

We found no association with the Lys751Gln and Arg $112 \mathrm{His}$ genotype and melanoma or breast cancer risk. There were no statistically significant differences in Lys751Gln and Arg 112His genotype variant prevalence between early and late-onset cases. There were no major differences in the mean age of diagnosis between subjects carrying the $\mathrm{AA}, \mathrm{AC}$ or $\mathrm{CC}$ genotypes of Lys $751 \mathrm{Gln}$ change and the AA, AC or CC genotypes of Lys751 Gln change.

No association was observed between the Gly 156 Gly genotype and melanoma risk, for either early or late-onset melanoma. There was no major difference in the mean age of diagnosis between the subjects carrying $\mathrm{AA}, \mathrm{AC}$ or $\mathrm{CC}$ genotypes.

We found an association of the Lys751Gln CC/Asp312Asn_AA genotype with breast cancer risk (Table 7). The genotype was significantly over-represented among early-onset breast cancer patients $(O R=1.5, p=0.0212)$ and late onset cases $(O R=1.5$, $p=0.0169)$. No association between compound heterozygous carriers of Lys751 Gln and Asp312Asn variants and melanoma risk was observed (Table 7). The genotype Lys751Gln_CC/Asp312Asn_GG [42] is rare in our population $(1.7 \%$ in $M M$ and $1.6 \%$ in the control group).

Subjects carrying Lys751GIn_CC genotype and Gly156Gly_CC genotype were associated with modest increase of melanoma risk $(O R=1.4)$. In a subgroup of late-onset melanoma patients the genotype was more tightly associated with melanoma risk with $\mathrm{OR}=1.7, \mathrm{p}<0.05$ (Table 8).

There were no significant differences among carriers of Asp312Asn + Gly- 156Gly genotype and the risk of MM among early- and late-onset cases. The highest OR (1.4) and lowest $p$ value (0.088) reached was in the subgroup harbouring the Asp312Asn_AA/ Gly156Gly CC genotype.

Table 7. Lys $751 \mathrm{Gln} /$ Asp312Asn genotypes in the study and control groups

\begin{tabular}{|c|c|c|c|c|c|c|}
\hline Lys751Gln & Asp312Asn & $\begin{array}{l}\text { Melanoma } \\
(\mathrm{n}=423)\end{array}$ & $\begin{array}{l}\text { Newborns } \\
(n=1017)\end{array}$ & OR $(95 \% \mathrm{Cl}), \mathrm{p}$ & $\begin{array}{c}\text { Breast cancer } \\
(n=1713)\end{array}$ & OR $(95 \% \mathrm{Cl}), \mathrm{p}$ \\
\hline AA & GG & $\begin{array}{c}115 \\
(27.2 \%)\end{array}$ & $\begin{array}{c}267 \\
(26.3 \%)\end{array}$ & 1.0 (n.s.) & $\begin{array}{c}494 \\
(28.8 \%)\end{array}$ & 1.1 (n.s.) \\
\hline AA & $A G$ & $\begin{array}{c}28 \\
(6.6 \%)\end{array}$ & $\begin{array}{c}104 \\
(10.2 \%)\end{array}$ & 0.6 (n.s.) & $\begin{array}{c}153 \\
(8.9 \%)\end{array}$ & 0.9 (n.s.) \\
\hline AA & AA & $\begin{array}{c}2 \\
(0.5 \%)\end{array}$ & $\begin{array}{c}16 \\
(1.6 \%)\end{array}$ & 0.3 (n.s.) & $\begin{array}{l}17 \\
(1 \%)\end{array}$ & 0.6 (n.s.) \\
\hline$A C$ & GG & $\begin{array}{c}46 \\
(10.9 \%)\end{array}$ & $\begin{array}{c}107 \\
(10.5 \%)\end{array}$ & 1.0 (n.s.) & $\begin{array}{c}151 \\
(8.8 \%)\end{array}$ & 0.8 (n.s.) \\
\hline$A C$ & $A G$ & $\begin{array}{c}131 \\
(31 \%)\end{array}$ & $\begin{array}{c}334 \\
(32.8 \%)\end{array}$ & 1.0 (n.s.) & $\begin{array}{c}559 \\
(32.6 \%)\end{array}$ & 1.0 (n.s.) \\
\hline$A C$ & AA & $\begin{array}{c}28 \\
(6.6 \%)\end{array}$ & $\begin{array}{c}49 \\
(4.8 \%)\end{array}$ & 1.4 (n.s.) & $\begin{array}{c}77 \\
(4.5 \%)\end{array}$ & 1.0 (n.s.) \\
\hline $\mathrm{CC}$ & GG & $\begin{array}{c}7 \\
(1.6 \%)\end{array}$ & $\begin{array}{c}20 \\
(2 \%)\end{array}$ & 0.8 (n.s.) & $\begin{array}{c}22 \\
(1.3 \%)\end{array}$ & 0.7 (n.s.) \\
\hline $\mathrm{CC}$ & $A G$ & $\begin{array}{c}27 \\
(6.4 \%)\end{array}$ & $\begin{array}{c}51 \\
(5 \%)\end{array}$ & 1.3 (n.s.) & $\begin{array}{c}67 \\
(3.9 \%)\end{array}$ & 0.8 (n.s.) \\
\hline $\mathrm{CC}$ & AA & $\begin{array}{c}39 \\
(9.2 \%)\end{array}$ & $\begin{array}{c}69 \\
(6.8 \%)\end{array}$ & 1.4 (n.s.) & $\begin{array}{c}173 \\
(10.1 \%)\end{array}$ & $\begin{array}{c}1.5(1.2-2.1) \\
0.004(0.016)^{1}\end{array}$ \\
\hline
\end{tabular}

I $p$ value calculated with the $\chi^{2}$ test (Bonferroni adjusted value in parantheses) 
None of the compound heterozygous genotypes were significantly over-represented among melanoma cases. Carriers of the Lys751Gln_CC/Asp312 Asn_GG/ Gly156Gly $C C$ genotype had $O R=1.8$ with $p=0.5$. Carriers of the Lys751Gln_CC/Asp312Asn_AA/ Gly156Gly_CC genotype had $O R=1.3$ with $p=0.3$. The high $p$ value is due to the small numbers of carriers with all three polymorphisms.

Haplotype frequency analyses showed a statistically significant association in subjects carrying Lys751 Gln_C/ Gly156Gly_C genotype with modest increase of MM risk $(\mathrm{OR}=1.2 ; \mathrm{p}=0.007$ before Bonferroni correction; $p=0.028$ after Bonferroni correction). We found an association of the Lys751Gln_C/Asp312Asn_A genotype with breast cancer risk. The genotype was significantly over-represented ( $O R=1.2 ; p=0.049$ before Bonferroni correction, $p=0.2$ after Bonferroni correction). There was a similar situation with Lys $751 \mathrm{Gln} C /$ Asp312Asn $A$ / Gly156Gly_C genotype (OR=1.2; $p=0.008$ before Bonferroni correction, $p=0.065$ after Bonferroni correction).

\section{Summary of the results}

XPD genotype Lys751GIn_CC/Gly156Gly_CC was detected in $15 \%$ of 471 unselected malignant melanoma patients and $11 \%$ of controls $(O R=1.4)$.
Significant over-representation of this genotype was found in late-onset cases (over the age of 50, $\mathrm{OR}=1.7$, $p=0.007, p=0.042$ after Bonferroni correction).

XPD genotype Lys751Gln_CC/Asp312Asn_AA was detected in $10 \%$ of 1830 unselected breast cancer patients and $6.8 \%$ of controls. This difference was statistically significant $p=0.004 \quad(p=0.016$ after Bonferroni correction) and $\mathrm{OR}=1.5$.

\section{MCIR common variants, CDKN2A and their association with melanoma and breast cancer risk}

(based on Debniak T, Scott R, Masojc B, Serrano-Fernandez P, Huzarski T, Byrski T, Debniak B, Gorski B, Cybulski C, Medrek K, Kurzawski G, van de Wetering T, Maleszka R, Kladny J, Lubinski J. MCIR common variants, CDKN2A and their association with melanoma and breast cancer risk. Int J Cancer 2006; 1 19: 2597-2602)

One of the melanoma low-penetrance susceptibility genes is MCIR. The MCIR gene (16q24, OMIM 155555) encodes a protein that acts as the receptor for melanocyte-stimulating hormone (MSH). It has been reported that some germline allelic variants of $M C l R$

Table 8. Lys $751 \mathrm{Gln} / \mathrm{Gly} 156 \mathrm{Gly}$ genotypes among melanoma and control groups

\begin{tabular}{|c|c|c|c|c|c|c|}
\hline Lys751Gln & Gly156Gly & $\begin{array}{l}\text { Melanoma (MM) } \\
\quad(n=424)\end{array}$ & $\begin{array}{l}\text { Newborns } \\
(n=1052)\end{array}$ & $95 \% \mathrm{Cl}$ & $p$ & OR \\
\hline AA & AA & 56 (13.2\%) & 157 (14.9\%) & - & n.s. & 0.9 \\
\hline AA & CA & 70 (16.5\%) & 182 (17.3\%) & - & n.s. & 1 \\
\hline AA & $\mathrm{CC}$ & $19(4.5 \%)$ & $62(5.9 \%)$ & - & n.s. & 0.7 \\
\hline$A C$ & AA & $7(1.65 \%)$ & $25(2.4 \%)$ & - & n.s. & 0.7 \\
\hline$A C$ & CA & 130 (30.66\%) & 318 (30.2\%) & - & n.s. & 1 \\
\hline$A C$ & $\mathrm{CC}$ & 66 (15.57\%) & 153 (14.6\%) & - & n.s. & 1.1 \\
\hline $\mathrm{CC}$ & AA & $2(0.50 \%)$ & $2(0.2 \%)$ & - & n.s. & 2.5 \\
\hline $\mathrm{CC}$ & CA & $9(2.12 \%)$ & $36(3.4 \%)$ & - & n.s. & 0.6 \\
\hline CC & $\mathrm{CC}$ & 65 (15.3\%) & 117 (11.12\%) & $1.044-2.006$ & $0.03(0.18)$ & 1.4 \\
\hline $\mathrm{CC}$ & $\mathrm{CC}$ & $\begin{array}{c}M M \leq 50 \\
(n=172) \\
21(12.2 \%)\end{array}$ & 117 (11.12\%) & - & n.s. & 1.1 \\
\hline $\mathrm{CC}$ & $\mathrm{CC}$ & $\begin{array}{c}M M>50 \\
(n=250) \\
44(17.6 \%)\end{array}$ & 117 (11.12\%) & $1.170-2.491$ & $0.007(0.042)$ & 1.7 \\
\hline
\end{tabular}

$\mathrm{p}$ value calculated with the $\div 2$ test (Bonferroni adjusted value in parantheses)

${ }^{1}$ age at onset unknown in two cases of melanoma 
gene (Arg151Cys, Arg 160Trp, Asp294His) are associated with an increased risk of multiple melanomas (MM) [43-45]. They also act as modifiers of melanoma risk in carriers of CDKN2A mutations by increasing disease penetrance in familial melanoma cases. However, the majority of these reports suggesting an association were based on the examination of melanoma-prone families $[46,47]$. The risk of MM has only been evaluated in fair-skinned populations of northern European [44, 48, 49] origin and in Mediterranean populations [47, 50-53].

Recently Begg et al. pointed out that CDKN2A mutation carriers in the general population have a much lower risk of melanoma than that suggested by estimates obtained from multiple-case families [54]. Similarly, the increase of CDKN2A penetrance caused by MC1R variants may also be lower in the general population.

To evaluate malignant melanoma risk among carriers of common germline MCIR changes the protein coding sequence of this gene was analysed and the frequencies of detected DNA alterations were evaluated among cases and controls. In order to evaluate the phenotypic characterisation of the patient population we included information on family aggregation and clinical data in the analyses.

$M C 1 R$ has recently been suggested to act on MM risk via non-pigmentary mechanisms [50]. Its variant has been reported to be associated with prostate cancer risk. Since melanoma and breast cancer appear to share some genetic background we also examined the prevalence of the MCIR variants among unselected breast cancer patients.

\section{Materials and methods}

The sequencing was performed in $40 \mathrm{MM}$ patients from families with at least two diagnosed cases among first-degree relatives.

The association research was performed on two case groups. The first case group consisted of 500 unselected MM patients diagnosed in few centres in Poland. The second study population consisted of 511 prospectively ascertained cases of consecutive invasive breast cancer diagnosed in the city of Szczecin.

The control group consisted of 800 geographically matched newborn male and female children collected in the same hospitals from where the melanoma and breast cancer cases were collected: 421 healthy adults matched for sex and age with the melanoma cases and 511 healthy women from the region of Szczecin matched for sex and age with the breast cancer cases collected from the city of Szczecin.

From the sequencing results 4 common variants were identified: V60L, R151C, R163Q and R160W.
The frequency of the $4 M C 1 R$ variants was identified by RFLP-PCR by use of enzyme: Hha I for R151C; Hindlll for R163Q; Sacll for R160W. The V60L variant was analyzed using an allele-specific PCR (ASO-PCR).

A separate DNA sample was sequenced to confirm the presence of the mutation.

The study was approved by the ethics board of the Pomeranian Medical University in Szczecin.

\section{Results}

Genomic sequencing of the 40 familial cases of MM revealed 9 different SNPs. Four of them (V6OL, R151C, R163Q and R160W) were regarded as common variants (they were detected in at least $10 \%$ of familial cases) and used in further analyses.

There were no significant differences in the allele frequencies of the MCIR variants in the 2 control populations. Since only the newborn group consisted of cases geographically matching the melanoma and breast cancer patients, and as it was larger than the adult control population, further statistical calculations were performed only on this control group.

\section{Haplotype analysis in melanoma patient population}

We found a statistically significant association of the R151C variant ( $p=0.000008$; OR $52.9,95 \% \mathrm{Cl}$ 1.82-4.67), the V60L variant ( $p=0.007$; OR 5 1.78; $95 \% \mathrm{Cl} 1.2-2.64)$, the R160C variant $(p=0.006$; OR $51.76 ; 95 \% \mathrm{Cl} 1.75-2.62)$ and the $\mathrm{R} 163 \mathrm{Q}$ variant $(p=0.015$; OR $52.195 \% \mathrm{Cl} 1.1-3.97)$ with melanoma risk.

The presence of any of those 4 common MCIR variants was significantly higher among patients than in the control population $(p=0.0000004)$.

Additionally the association between carriers of the common A 148T variant of CDKN2A and the $4 \mathrm{MC} 1 \mathrm{R}$ polymorphisms was evaluated. None of the compound heterozygotes were significantly over-represented among any of the melanoma cases (data not shown). Nevertheless, the highest OR (4.2) was observed in patients harbouring the A148T variant in CDKN2A and the $\mathrm{R} 151 \mathrm{C}$ variant in MC1R.

Although the average age at diagnosis of carriers was always 1-2 years lower than among non-carriers, for each of the 4 common MCIR variants separately, none of these differences was significant. However, there was a statistically significant difference of almost 6 years ( $t$-test, one-tailed; $p=0.039$ ) when comparing the age at diagnosis of compound carriers (average 48.4 years) with non-carriers (average 54.2 years).

There was a significantly higher frequency of melanoma occurrence among first-degree relatives of 
carriers of any of the $M C l R$ variants in comparison to non-carriers $(p=0.03 ; O R=3.6)$. Analogously there was a slight increase in the prevalence of all MCIR variants among melanoma probands with a first- or second-degree relative affected by melanoma $(7 / 40$; $17.5 \%)$ when compared to unselected cases (73/474; $15.4 \%)$.

There were no significant differences in frequency of breast cancer in first-degree relatives and in patients without changes in the MCIR gene (Table 9).

The analysis of the clinical data revealed a significant increase of melanoma occurrence on non-exposed skin areas among carriers of any of the MCIR variants (p 5 0.0014; OR 5 2.2). We also observed an almost 5 -fold increase of multiplicity of melanoma among carriers of any of the MCIR variants. There was no association between those variants and tumour type (Table 10).

\section{Haplotype analysis in breast cancer patient population}

We found no association with the MCIR variants and breast cancer risk. There were no statistically significant differences in the prevalence of the MClR

Table 9. Occurrence of melanoma and breast cancer among first-degree relatives of MM probands

\begin{tabular}{|c|c|c|c|c|c|}
\hline \multirow{2}{*}{$\begin{array}{l}\text { Feature } \\
\text { first-degree relatives } \\
\text { affected with }\end{array}$} & \multicolumn{2}{|c|}{ R160W } & \multirow[t]{2}{*}{$p$} & \multirow[t]{2}{*}{$95 \% \mathrm{Cl}$} & \multirow[t]{2}{*}{ OR } \\
\hline & $\begin{array}{c}\text { carriers }(+) \\
n=85\end{array}$ & $\begin{array}{c}\text { non-carriers (-) } \\
n=373\end{array}$ & & & \\
\hline melanoma $^{3}$ & $4(4.7 \%)^{1}$ & $17(4.5 \%)^{2}$ & n.s. & - & - \\
\hline \multirow[t]{3}{*}{ breast cancer $^{4}$} & $4(4.7 \%)$ & $25(6.7 \%)$ & n.s. & - & - \\
\hline & \multicolumn{2}{|c|}{ R151C } & & & \\
\hline & $\begin{array}{c}\text { carriers }(+) \\
n=74\end{array}$ & $\begin{array}{c}\text { non-carriers (-) } \\
n=401\end{array}$ & & & \\
\hline melanoma & 7 (9.5\%) & 11 (2.7\%) & 0.0097 & $1.276-9.061$ & 3.4 \\
\hline \multirow[t]{3}{*}{ breast cancer } & $5(6.7 \%)$ & $25(6.2 \%)$ & n.s. & - & - \\
\hline & \multicolumn{2}{|c|}{ V60L } & & & \\
\hline & $\begin{array}{c}\text { carriers }(+) \\
n=78\end{array}$ & $\begin{array}{c}\text { non-carriers (-) } \\
n=354\end{array}$ & & & \\
\hline melanoma & $5(6.4 \%)$ & $10(2.8 \%)$ & n.s. & - & 2.4 \\
\hline \multirow[t]{3}{*}{ breast cancer } & $5(6.4 \%)$ & $24(6.7 \%)$ & n.s. & - & - \\
\hline & \multicolumn{2}{|c|}{$\mathrm{R} 163 \mathrm{Q}$} & & & \\
\hline & $\begin{array}{c}\text { carriers }(+) \\
n=30\end{array}$ & $\begin{array}{c}\text { non-carriers (-) } \\
n=354\end{array}$ & & & \\
\hline melanoma & 1 (3.3\%) & $13(3.6 \%)$ & n.s & - & - \\
\hline \multirow[t]{3}{*}{ breast cancer } & $2(5 \%)$ & 17 (4.8\%) & n.s & - & - \\
\hline & $\begin{array}{c}\text { any of four } \\
\text { variants positive }\end{array}$ & $\begin{array}{c}\text { none of four } \\
\text { variants positive }\end{array}$ & & & \\
\hline & $\begin{array}{c}\text { carriers }(+) \\
n=245\end{array}$ & $\begin{array}{c}\text { non-carriers (-) } \\
n=149\end{array}$ & & & \\
\hline melanoma & 17 (6.9\%) & $3(2.0 \%)$ & 0.03 & $1.05-12.60$ & 3.6 \\
\hline breast cancer & $16(6.5 \%)$ & $8(5.4 \%)$ & n.s & - & - \\
\hline
\end{tabular}

lpercentage of carriers with at least one affected first-degree relative

${ }^{2}$ percentage of probands without MC1R variants but with at least one affected first-degree relative

${ }^{3}$ number of melanoma cases among first-degree relatives

${ }^{4}$ number of breast cancer cases among first-degree relatives 
Table 10. Clinical data comparison of carriers versus non-carriers of MClR variants

\begin{tabular}{|c|c|c|c|c|}
\hline Feature & Carriers (+) & Non-carriers (-) & $\mathrm{p}(95 \% \mathrm{Cl})$ & OR \\
\hline \multicolumn{5}{|c|}{ R160W } \\
\hline multiplicity? & $3 / 85^{2}(3.5 \%)$ & $6 / 374^{3}(1.6 \%)$ & n.s. & 2.2 \\
\hline localization-skin ${ }^{4}$ & $2.4^{5}$ & 1.3 & n.s. & 1.8 \\
\hline tumour type ${ }^{6}$ & $60^{7} / 20^{8} / 10^{9} / 4^{10}$ & $58 / 20 / 9 / 5$ & n.s. & \\
\hline \multicolumn{5}{|c|}{ R151C } \\
\hline multiplicity & $3 / 73(4.1 \%)$ & 7/402 (1.7\%) & n.s. & 2.4 \\
\hline localization in skin & 2.2 & 1.4 & n.s. & 1.5 \\
\hline tumour type & $57 / 21 / 9 / 5$ & $54 / 19 / 10 / 6$ & n.s. & \\
\hline \multicolumn{5}{|c|}{ V60L } \\
\hline multiplicity & $2 / 78(2.6 \%)$ & $6 / 355$ (1.7\%) & n.s. & 1.5 \\
\hline localization in skin & 2.0 & 1.4 & n.s. & 1.4 \\
\hline tumour type & $58 / 22 / 11 / 4$ & $57 / 20 / 11 / 3$ & n.s. & \\
\hline \multicolumn{5}{|c|}{ R163Q } \\
\hline multiplicity & $1 / 30(3.3 \%)$ & $8 / 355(2.2 \%)$ & n.s. & 1.5 \\
\hline localization in skin & 1.9 & 1.5 & n.s. & 1.3 \\
\hline \multirow[t]{2}{*}{ tumour type } & $60 / 19 / 10 / 5$ & $58 / 18 / 9 / 5$ & n.s. & \\
\hline & $\begin{array}{c}\text { any of four } \\
\text { variants positive }\end{array}$ & $\begin{array}{l}\text { none of four variants } \\
\text { positive }\end{array}$ & & \\
\hline multiplicity & $8 / 254(3.1 \%)$ & $1 / 149(0.7 \%)$ & n.s. & 4.8 \\
\hline localization in skin & 2.2 & 1.0 & $0.0014(1.35-3.63)$ & 2.2 \\
\hline tumour type & $61 / 21 / 8 / 5$ & $60 / 20 / 9 / 4$ & n.s. & \\
\hline
\end{tabular}

1synchronic or metachronic tumours

${ }^{2}$ number of multiple melanoma cases/total number of $M C 1 R$ variant carriers

3 number of multiple melanoma cases/total number of patients without MCIR variants

4 regions of exposed skin: head, nape, neck, forearms, palms, shanks, feet; regions of unexposed skin: trunk, thighs, arms, buttocks

5 unexposed to exposed skin ratio - number of melanomas in unexposed skin divided by number of melanomas in exposed skin

tyypes of melanoma: a) SSM-superficial spreading melanoma; b) NM-nodular melanoma; c) LM-lentigo melanoma; d) ALM-acral lentigo melanoma

7 SSM percentage

$8 \mathrm{NM}$ percentage

9LM percentage

${ }^{10} \mathrm{ALM}$ percentage

variants between early and late onset cases. None of the compound heterozygotes $(2$ or more MCIR changes, also MCIR alterations with the A148T CDKN2A variant) were significantly over-represented among cases (data not shown).

\section{Summary of the results}

Among 500 unselected MM the four variants of $M C 7 R$ gene were found more frequently in the control group: $\mathrm{R} 151 \mathrm{C}(15.4 \% \mathrm{MM} ; \mathrm{OR}=2.9 ; \mathrm{p}=0.000$ 008),
V60L (18.2\% MM; OR=1.8; $p=0.007), R 160 C$ (19.3\%; $O R=1.8 ; p=0.006)$ and $R 163 Q(7.8 \%$; $\mathrm{OR}=2.1 ; \mathrm{p}=0.015)$. In carriers of the mentioned changes $M M$ appears with higher frequency on non-exposed skin areas $(p=0.0014)$. Mentioned melanoma appears with higher frequency among first-degree relatives of carriers of mentioned changes of the MCIR gene ( $p=0.0097)$. We certify a statistically significant difference of almost 6 years in comparing the age at diagnosis of compound carriers of variants of the MCIR gene. 
The highest risk of affected MM was observed among carriers of $\mathrm{A} 148 \mathrm{~T}$ and $\mathrm{R} 151 \mathrm{C}$ variant $(\mathrm{OR}=4.2)$; there were no statistically significant data for subgroups of carriers with two or more changes in the MClR gene or carriers with A148T and MC1R genes.

Evaluation of 511 unselected breast cancer patients revealed no association with the MCIR variants and breast cancer risk.

\section{General conclusions}

The outcomes of our various studies lead us to the following conclusions.

Systematic breast surveillance beginning at the age 35-40 years should be considered as an option for women from families with strong cancer familial aggregation of malignancies of various site of origin and for women with malignant melanoma diagnosed under 56 years of life. The outcome of such surveillance would need to be monitored in a research setting to determine its clinical value.

In the Polish population CDKN2A and ARF do not contribute significantly to either familial melanoma or malignant melanoma within the context of a cancer familial aggregation of disease with breast cancer. Therefore, in this population, there appears to be no strong indication for CDKN2A and ARF testing in these familial cases.

The common variant of the CDKN2A gene A148T, previously regarded as non-pathogenic, may predispose to malignant melanoma, early-onset breast cancer and lung cancer. A148T is significantly over-represented in women with early-onset breast cancer and may predispose to intraductal cancers (DCIS) with micro-invasion. It seems thus justified to propose mammography, in a research setting, beginning at the age of 35 as an option for carriers of the A148T variant.

Compound carriers of common XPD variants may be at slightly increased risk of breast cancer or late-onset malignant melanoma.

Common recurrent variants of the MCIR gene (V60L, R151C, R163Q and R160W) may predispose to malignant melanoma.

In general, the establishment of surveillance protocols proposed as an option for carriers of common alterations in CDKN2A, XPD or MC1R variants requires additional studies.

All the above-mentioned variants are low-penetrant changes characterized by a negative cancer family history. Thus, the use of DNA tests is the only way to find carriers of these changes with increased risk of tumour development. Identification of low penetrance
DNA alterations may be very important if the simultaneous presence of such alternations and/or combinations with external risk factors in a carrier would add up to a clinically significant high risk of tumour development. It will be a big challenge to study the possible cumulative effects on cancer risk of the many different combinations of low-penetrance mutations. Studies of this kind will need very large cohorts to establish reliable risk estimates.

\section{References}

1. The Breast Cancer Linkage Consortium. Cancer risks in BRCA2 mutation carriers. J Natl Cancer Inst 1999; 91: 1310-1316.

2. Weston B, Grufferman S, Kostyu D, Burton CS, Grant J. Familial aggregation of melanoma, basal cell carcinoma, and gastric adenocarcinoma. Cancer 1986; 57: 2230-2234.

3. Hemminki K, Dong C. Subsequent cancers after in situ and invasive squamous cell carcinoma of the skin. Arch Dermatol 2000; 136: 647-651.

4. Azizi E, Friedman J, Pavlotsky F, Iscovich J, Bornstein A, Shafir R, Trau $H$, Brenner $H$, Nass D. Familial cutaneous malignant melanoma and tumors of the nervous system. A hereditary cancer syndrome. Cancer 1995; 76: 1571-1578.

5. Soufir N, Avril MF, Chompret A, Demenais F, Bombled J, Spatz A, Stoppa-Lyonnet D, Benard J, Bressac-de Paillerets B. Prevalence of p16 and CDK4 germline mutations in 48 melanoma-prone families in France. The French Familial Melanoma Study Group Hum Mol Genet 1998; 7: 209-216.

6. Fitzgerald MG, Harkin DP, Silva-Arrieta S, MacDonald DJ, Lucchina LC, Unsal H, O’Neill E, Koh J, Finkelstein DM, Isselbacher KJ, Sober AJ, Haber DA. Prevalence of germ-line mutations in p16, p19ARF, and CDK4 in familial melanoma: analysis of a clinic-based population. Proc Natl Acad Sci USA 1996; 93: 8541-8545.

7. Platz A, Hansson J, Ringborg U. Screening of germline mutations in the CDK4, CDKN2C and TP53 genes in familial melanoma: a clinic-based population study. Int J Cancer 1998; 25: 13-15.

8. Platz A, Hansson J, Mansson-Brahme E, Lagerlof B, Linder S, Lundqvist $E$, Sevigny $P$, Inganas $M$, Ringborg $U$. Screening of germline mutations in the CDKN2A and CDKN2B genes in Swedish families with hereditary cutaneous melanoma. J Natl Cancer Inst 1997; 89: 697-702.

9. Lamperska K, Karezewska A, Kwiatkowska E, Mackiewicz A. Analysis of mutations in the p16/CDKN2A gene in sporadic and familial melanoma in the Polish population. Acta Biochim Pol 2002; 49: 369-376.

10. Randerson-Moor JA, Harland M, Williams S, Cuthbert-Heavens D, Sheridan E, Aveyard J, Sibley K, Whitaker L, Knowles M, Bishop JN, Bishop DT. A germline deletion of p1 4 (ARF) but not CDKN2A in a melanoma-neural system tumour syndrome family. Hum Mol Genet 2001; 10: 55-62.

11. Hewitt C, Lee Wu C, Evans G, Howell A, Elles RG, Jordan R, Sloan P, Read AP, Thakker N. Germline mutation of ARF in a melanoma kindred. Hum Mol Genet 2002; 11 : 1273-1279.

12. Bahuau M, Vidaud D, Jenkins RB, Bieche I, Kimmel DW, Assouline B, Smith JS, Alderete B, Cayuela JM, Harpey JP, Caille B, Vidaud M.. Germline deletion involving the INK4 locus in familial proneness to melanoma and nervous system tumors. Cancer Res 1998; 58: 2298-2303.

13. Hogervorst FB, Nederlof PM, Gille JJ, McElgunn CJ, Grippeling M, Pruntel R, Regnerus R, van Welsem T, van Spaendonk R, 
Menko FH, Kluijt I, Dommering C, Verhoef S, Schouten JP, van't Veer LJ, Pals G. Large genomic deletions and duplications in the BRCAl gene identified by a novel quantitative method. Cancer Res 2003; 63: 1449-1453.

14. Nakagawa $H$, Hampel $H$, de la Chapelle $A$. Identification and characterization of genomic rearrangements of $\mathrm{MSH} 2$ and $\mathrm{MLH} 1$ in Lynch syndrome (HNPCC) by novel techniques. Hum Mutat 2003; 22: 258

15. Lahiri DK, Schnabel B. DNA isolation by rapid method from human blood samples: effects of $\mathrm{MgCl} 2$, EDTA, storage time, and temperature on DNA yield and quality. Biochem Genet 1993; $31: 321-328$.

16. Kumar R, Smeds J, Berggren P, Straume O, Rozell BL, Akslen LA, Hemminki K. A single nucleotide polymorphism in the 3 'untranslated region of the CDKN2A gene is common in sporadic primary melanomas but mutations in the CDKN2B, CDKN2C, CDK4 and p53 genes are rare. Int J Cancer 2001 95: 388-393

17. Straume O, Smeds J, Kumar R, Hemminki K, Akslen LA Significant impact of promoter hypermethylation and the 540 C $>$ T polymorphism of CDKN2A in cutaneous melanoma of the vertical growth phase. Am J Pathol 2002; 161: 229-237.

18. Aitken J, Welch J, Duffy D, Milligan A, Green A, Martin N, Hayward N. CDKN2A variants in a population-based sample of Queensland families with melanoma. J Natl Cancer Inst 1999; 91 : 446-452

19. Ranade K, Hussussian CJ, Sikorski RS, Varmus HE, Goldstein AM, Tucker MA, Serrano M, Hannon GJ, Beach D, Dracopoli NC. Mutations associated with familial melanoma impair pl 6INK4 function. Nat Genet 1995; 10: 114-116.

20. Lilischkis R, Sarcevic B, Kennedy C, Warlters A, Sutherland RL. Cancer-associated mis-sense and deletion mutations impair pl6INK4 CDK inhibitory activity. Int J Cancer 1996; 66 249-254.

21. Serrano M, Hannon GJ, Beach D. A new regulatory motif in cell-cycle control causing specific inhibition of cyclin D/CDK4 Nature 1993; 366: 704-707.

22. Borg A, Sandberg T, Nilsson K, Johannsson O, Klinker M, Masback A, Westerdahl J, Olsson $\mathrm{H}$, Ingvar $\mathrm{C}$. High frequency of multiple melanomas and breast and pancreas carcinomas in CDKN2A mutation-positive melanoma families. J Natl Cancer Inst 2000; 92: 1260-1266.

23. Whelan AJ, Bartsch D, Goodfellow PJ. Brief report: a familial syndrome of pancreatic cancer and melanoma with a mutation in the CDKN2 tumor-suppressor gene. N Eng J Med 1995; 333: 975-977.

24. Van Zee KJ, Calvano JE, Bisogna M. Hypomethylation and increased gene expression of pl6INK4a in primary and metastatic breast carcinoma as compared to normal breast tissue. Oncogene 1998; 16: 2723-2727.

25. Ghiorzo P, Ciotti P, Mantelli M, Heouaine A, Queirolo P, Rainero ML, Ferrari C, Santi PL, De Marchi R, Farris A, Ajmar F, Bruzzi P, Bianchi-Scarra G. Characterization of ligurian melanoma families and risk of occurrence of other neoplasia. Int J Cancer 1999; 83: $441-448$

26. Nielsen NH, Roos G, Emdin SO, Landberg G. Methylation of the p16 (Ink4a) tumor suppressor gene 5"-CpG island in breast cancer. Cancer Lett 2001; 163: 59-69.

27. Gorgoulis VG, Koutroumbi EN, Kotsinas A, Zacharatos P, Markopoulos C, Giannikos L, Kyriakou V, Voulgaris Z, Gogas I, Kittas C. Alterations of p 16-pRb pathway and chromosome locus 9p21-22 in sporadic invasive breast carcinomas. Mol Med 1998; 4: 807-822.

28. Schneider-Stock R, Giers A, Motsch C, Boltze C, Evert M, Freigang $B$, Roessner A. Hereditary p 16-Leiden mutation in a patient with multiple head and neck tumors. Am J Hum Genet 2003; 72: 216-218.

29. Belinsky SA, Nikula KJ, Palmisano WA, Michels R, Saccomanno G, Gabrielson E, Baylin SB, Herman JG. Aberrant methylation of pl6 (INK4a) is an early event in lung cancer and a potential biomarker for early diagnosis. Proc Natl Acad Sci USA 1998; 95: $11891-11896$.

30. Smigiel R, Sasiadek M, Krecicki T, Ramsey D, Jagielski J, Blin N. Inactivation of the cyclin-dependent kinase inhibitor $2 \mathrm{~A}$ (CDKN2A) gene in squamous cell carcinoma of the larynx. Mol Carcinog 2004; 39: 147-154.

31. Tsao H. Update on familial cancer syndromes and the skin. J Am Acad Dermatol 2000; 42: 939-970.

32. Cleaver JE, Thompson LH, Richardson AS, States JC. A summary of mutations in the UV-sensitive disorders: xeroderma pigmentosum, Cockayne syndrome, and trichothiodystrophy. Hum Mutat 1999; 14: 9-22.

33. Berneburg M, Lehmann AR. Xeroderma pigmentosum and related disorders: defects in DNA repair and transcription. Adv Genet 2001; 43: 71 -102.

34. Broughton BC, Steingrimsdottir $H$, Weber CA, Lehmann AR. Mutations in the xeroderma pigmentosum group D DNA repair/transcription gene in patients with trichothiodystrophy. Nat Genet 1994; 7: 189-194.

35. Tomescu D, Kavanagh G, Ha T, Campbell H, Melton DW. Nucleotide excision repair gene XPD polymorphisms and genetic predisposition to melanoma. Carcinogenesis 2001 ; 22: 403-408.

36. Winsey SL, Haldar NA, Marsh HP, Bunce M, Marshall SE, Harris $\mathrm{AL}$, Wojnarowska F, Welsh KI. A variant within the DNA repair gene XRCC3 is associated with the development of melanoma skin cancer. Cancer Res 2000; 60: 5612-5616.

37. Han J, Colditz GA, Liu JS, Hunter DJ. Genetic variation in XPD, sun exposure, and risk of skin cancer. Cancer Epidemiol Biomarkers Prev 2005; 14: 1539-1544.

38. Baccarelli A, Calista D, Minghetti P, Marinelli B, Albetti B, Tseng T, Hedayati M, Grossman L, Landi G, Struewing JP, Landi MT. XPD gene polymorphism and host characteristics in the association with cutaneous malignant melanoma risk. $\mathrm{Br} \mathrm{J}$ Cancer 2004; 90: 497-502.

39. Justenhoven C, Hamann U, Pesch B, Harth V, Rabstein S, Baisch C, Vollmert C, Illig T, Ko YD, Bruning T, Brauch H. ERCC2 genotypes and a corresponding haplotype are linked with breast cancer risk in a German population. Cancer Epidemiol Biomarkers Prev 2004; 13: 2059-2064.

40. Zhang L, Zhang Z, Yan W. Single nucleotide polymorphisms for DNA repair genes in breast cancer patients. Clin Chim Acta 2005; 359: 150-155.

41. Forsti A, Angelini S, Festa F, Sanyal S, Zhang Z, Grzybowska E, Pamula J, Pekala W, Zientek H, Hemminki K, Kumar R. Single nucleotide polymorphisms in breast cancer. Oncol Rep 2004; $11:$ 917-922.

42. Hashemi J, Platz A, Ueno T, Stierner U, Ringborg U, Hansson J. CDKN2A germ-line mutations in individuals with multiple cutaneous melanomas. Cancer Res 2000; 60: 6864-6867.

43. Valverde P, Healy E, Jackson I, Rees JL, Thody AJ. Variants of the melanocyte stimulating hormone receptor gene are associated with red hair and fair skin in humans. Nat Genet 1995; 11 : 328-330.

44. Palmer JS, Duffy DL, Box NF, Aitken JF, O'Gorman LE, Green AC, Hayward NK, Martin NG, Sturm RA. Melanocortin-1 receptor polymorphisms and risk of melanoma: is the association explained solely by pigmentation phenotype? Am J Hum Genet 2000; 66: 176-186.

45. Box NF, Wyeth JR, O'Gorman LE, Martin NG, Sturm RA. Characterization of melanocyte stimulating hormone receptor 
variant alleles in twins with red hair. Hum Mol Genet 1997; 6: 1891-1897.

46. Box NF, Duffy DL, Chen W, Stark M, Martin NG, Sturm RA Hayward NK. MCIR genotype modifies risk of melanoma in families segregating CDKN2A mutations. Am J Hum Genet 2001; 69: 765-773.

47. Chaudru V, Laud K, Avril MF, Miniere A, Chompret A, Bressac-de Paillerets B, Demenais F. Melanocortin-1 receptor (MC1R) gene variants and dysplastic nevi modify penetrance of CDKN2A mutations in French melanoma-prone pedigrees. Cancer Epidemiol Biomarkers Prev 2005; 14: 2384-2390.

48. Kennedy C, ter Huurne J, Berkhout M, Gruis N, Bastiaens M, Bergman W, Willemze R, Bavinck JN. Melanocortin 1 receptor (MCIR) gene variants are associated with an increased risk for cutaneous melanoma which is largely independent of skin type and hair color. J Invest Dermatol 2001; 1 17: 294-300.

49. Valverde P, Healy E, Sikkink S, Haldane F, Thody AJ, Carothers A, Jackson IJ, Rees JL. The Asp84Glu variant of the melanocortin 1 receptor (MC1R) is associated with melanoma. Hum Mol Genet 1996; 5: 1663-1666.

50. Matichard E, Verpillat P, Meziani R, Gerard B, Descamps V, Legroux E, Burnouf $M$, Bertrand $G$, Bouscarat $F$, Archimbaud $A$, Picard C, Ollivaud L, Basset-Seguin N, Kerob D, Lanternier G, Lebbe C, Crickx B, Grandchamp B, Soufir N. Melanocortin 1 receptor (MC1R) gene variants may increase the risk of melanoma in France independently of clinical risk factors and UV exposure. J Med Genet 2004; 41 : e13.

51. Landi MT, Kanetsky PA, Tsang S, Gold B, Munroe D, Rebbeck T, Swoyer J, Ter-Minassian M, Hedayati M, Grossman L, Goldstein AM, Calista D, Pfeiffer RM. MC1R, ASIP, and DNA repair in sporadic and familial melanoma in a Mediterranean population. J Natl Cancer Inst 2005; 97: 998-1007.

52. Stratigos AJ, Dimisianos G, Nikolaou V, Poulou M, Sypsa V Stefanaki I, Papadopoulos O, Polydorou D, Plaka M, Christofidou E, Gogas H, Tsoutsos D, Kastana O, Antoniou C, Hatzakis A, Kanavakis E, Katsambas AD. Melanocortin receptor-1 gene polymorphisms and the risk of cutaneous melanoma in a low-risk southern European population. J Invest Dermatol 2006; 126: 1842-1849.

53. Fargnoli MC, Altobelli E, Keller G, Chimenti S, Hofler H, Peris K. Contribution of melanocortin- 1 receptor gene variants to sporadic cutaneous melanoma risk in a population in central Italy: a case-control study. Melanoma Res 2006; 16: 175-182.

54. Begg CB, Orlow I, Hummer AJ, Armstrong BK, Kricker A, Marrett LD, Millikan RC, Gruber SB, Anton-Culver H, Zanetti R, Gallagher RP, Dwyer T, Rebbeck TR, Mitra N, Busam K, From L, Berwick M. Genes Environment and Melanoma Study Group. Lifetime risk of melanoma in CDKN2A mutation carriers in a population-based sample. J Natl Cancer Inst 2005; 97: 1507-1515. 